\title{
The Interjurisdictional Effects of Growth Controls on Housing Prices
}

\section{Citation}

Katz, Lawrence F., and Kenneth T. Rosen. 1987. The interjurisdictional effects of growth controls on housing prices. Journal of Law and Economics 30(1): 149-160.

\section{Published Version}

http://dx.doi.org/10.1086/467133

\section{Permanent link}

http://nrs.harvard.edu/urn-3:HUL.InstRepos:3442758

\section{Terms of Use}

This article was downloaded from Harvard University's DASH repository, and is made available under the terms and conditions applicable to Other Posted Material, as set forth at http:// nrs.harvard.edu/urn-3:HUL.InstRepos:dash.current.terms-of-use\#LAA

\section{Share Your Story}

The Harvard community has made this article openly available.

Please share how this access benefits you. Submit a story.

Accessibility 


\section{CHICAgo journals}

The Interjurisdictional Effects of Growth Controls on Housing Prices

Author(s): Lawrence Katz and Kenneth T. Rosen

Source: Journal of Law and Economics, Vol. 30, No. 1 (Apr., 1987), pp. 149-160

Published by: The University of Chicago Press

Stable URL: http://www.jstor.org/stable/725395

Accessed: 07 $/ 12 / 2009$ 13:40

Your use of the JSTOR archive indicates your acceptance of JSTOR's Terms and Conditions of Use, available at http://www.jstor.org/page/info/about/policies/terms.jsp. JSTOR's Terms and Conditions of Use provides, in part, that unless you have obtained prior permission, you may not download an entire issue of a journal or multiple copies of articles, and you may use content in the JSTOR archive only for your personal, non-commercial use.

Please contact the publisher regarding any further use of this work. Publisher contact information may be obtained at http://www.jstor.org/action/showPublisher?publisherCode=ucpress.

Each copy of any part of a JSTOR transmission must contain the same copyright notice that appears on the screen or printed page of such transmission.

JSTOR is a not-for-profit service that helps scholars, researchers, and students discover, use, and build upon a wide range of content in a trusted digital archive. We use information technology and tools to increase productivity and facilitate new forms of scholarship. For more information about JSTOR, please contact support@jstor.org.

The University of Chicago Press is collaborating with JSTOR to digitize, preserve and extend access to Journal of Law and Economics. 


\section{THE INTERJURISDICTIONAL EFFECTS OF GROWTH CONTROLS ON HOUSING PRICES*}

LAWRENCE KATZ

Harvard University and National Bureau of Economic Research and

KENNETH T. ROSEN

University of California, Berkeley

\section{INTRODUCTION}

$\mathrm{I}_{\mathrm{N}}$ $\mathrm{N}$ recent years in the United States, government regulation of the housing industry has increased dramatically. During the late 1960s and early 1970s, many communities became increasingly dissatisfied with the effects of rapid, unregulated suburban growth on the overall quality of life. This increased awareness of the environmental, social, and economic effects of new residential development led to a widespread proliferation of land-use and environmental regulations. While this growth of regulation has proceeded at all levels of government, the bulk of control over residential development remains in the hands of local governments. This increase in land-use controls means that the home-building industry has to work within a much more complex and often costly regulatory framework.

Local governments use a wide variety of procedures to control the location, timing, character, and amount of residential development. Traditionally, communities have relied on zoning and subdivision ordinances, building codes, and communitywide land-use plans as the major tools for the regulation of new development. In recent years, more sophisticated and complex regulatory procedures have been developed and utilized widely by municipalities. In many communities, traditional landuse controls have been augmented by environmental and fiscal effect procedures, urban growth management systems, utility connection mora-

* We thank Dennis Carlton and an anonymous referee for their helpful comments and Eric Zivot for able research assistance. This research was supported in part by the Center for Real Estate and Urban Economics at the University of California, Berkeley.

[Journal of Law \& Economics, vol. XXX (April 1987)]

(C) 1987 by The University of Chicago. All rights reserved. $0022-2186 / 87 / 3001-0004 \$ 01.50$ 
toria, multiple-permit systems, overall growth limitations, or a combination of those measures.

The traditional, asserted purpose of land-use controls is to promote the health, safety, and general welfare of residents of a community. Increasingly stringent land-use regulations and growth controls have been justified in terms of improved environmental quality and the maintenance of "community character." Yet there is a growing recognition that in many communities land-use regulations may serve to maintain housing costs at a level high enough to prevent moderate- or low-income families from purchasing housing. The apparent effect of the new trend in land-use regulation appears to have been substantial increases in the cost of new housing production and subsequent increases in the prices of all housing.

Land-use and environmental regulations can have important effects on almost every component of housing costs. Regulations that restrict the supply of land for development, impose a minimum lot size, or restrain the permissible level of residential development density can greatly increase raw land costs. Regulations concerning improvements, the provision of amenities, and subdivision design can add significantly to the cost of lot preparation and land development. The costs of structural material and labor can be increased by building codes and other regulations that designate minimum house size or require major changes in house design. Substantial carrying costs can be imposed by administrative delays and by the often lengthy intervals required to gain development approval. Regulatory compliance can also affect various administrative, engineering, and planning costs. Dowall ${ }^{1}$ suggests that land-use controls may have another inflationary effect-creating barriers to entry, which facilitate monopoly power in the housing industry. Dowall and especially Frieden ${ }^{2}$ note that development restrictions may lead developers to reorient their projects to higher-income customers as cost increases force them to build more expensive dwelling units.

In this paper we examine the effects of local land-use regulations on house prices in the San Francisco Bay Area. ${ }^{3}$ The research is primarily empirical, although we present a brief discussion of theoretical and econometric issues.

${ }^{1}$ David E. Dowall, The Effect of Land Use and Environmental Regulations on Housing Costs, 8 Pol'y Stud. J. 277 (1979).

${ }^{2}$ Bernard J. Frieden, The New Regulation Comes to Suburbia, 55 Pub. Interest 15 (1979).

${ }^{3}$ A discussion of the evolution and nature of local land-use controls and growthmanagement programs in the San Francisco Bay Area may be found in Kenneth T. Rosen \& Lawrence Katz, Growth Management and Land Use Controls: The San Francisco Bay Area Experience, 9 J. Am. Real Est. \& Urb. Econ. A. 321 (1981). 


\section{The Interjurisdictional EfFects of Local Land-Use Controls on Housing Prices}

A potentially important effect of local land-use controls on the housing market of a metropolitan area is to reduce the supply below and to raise prices above what would prevail in competitive equilibrium with no landuse restrictions. A number of theoretical models, such as those presented in Courant, ${ }^{4}$ Rubinfeld, ${ }^{5}$ and Hamilton, ${ }^{6}$ demonstrate that, in both open and closed market areas, zoning restrictions for any defined metropolitan area are likely to increase house prices throughout that area. The issue of the interjurisdictional effects of local land-use policies on housing prices within a given urban area has not, however, been addressed as thoroughly in the literature. The basic issue here is whether a jurisdiction that is small relative to the metropolitan area, by the use of development restrictions, will raise its house prices relative to those prevailing in the rest of the metropolitan area. This interjurisdictional effect depends on the degree of substitutability among the housing stocks of different municipalities within an urban area and on the effect of land-use policies both on the labor market and on neighborhood amenities.

At one extreme, the population of a metropolitan area may be perfectly mobile across municipalities. This means that individual jurisdictions are perfect competitors in the production of housing services. This implies that houses with equivalent characteristics and amenity values located in different jurisdictions will be perfect substitutes. Following Courant, ${ }^{7}$ assume that all consumers in the metropolitan area are identical and have the same income. This implies that the price of housing at each amenity level (amenities being public services, access to work, and so on) must be the same for all jurisdictions in the metropolitan area to be in equilibrium. In this extreme case, local land-use policies can have no interjurisdictional effect on the price of a house with a given amenity package. Local policies can change housing prices among municipalities only by altering amenity values. Yet a major effect of density controls, large-lot zoning, and growth restrictions may be to improve amenities. For example, these policies may yield more open space and reduce both noise and congestion.

\footnotetext{
${ }^{4}$ Paul N. Courant, On the Effect of Fiscal Zoning on Land and Housing Values, 3 J. Urb. Econ. 88 (1976).

5 Daniel L. Rubinfeld, Suburban Employment and Zoning: A General Equilibrium Analysis, 18 J. Regional Sci. 33 (1978).

${ }^{6}$ Bruce W. Hamilton, Zoning and the Exercise of Monopoly Power, 5 J. Urb. Econ. 116 (1978).

${ }^{7}$ See note 4 supra.
} 
Rubinfeld ${ }^{8}$ has studied the dynamics of housing prices and their interaction with labor markets, using a model that includes a central business district and a suburban business district, part of which is in a zoned residential area. The regulation used in his model is large-lot zoning that constrains the allowable capital-to-land ratio and so affects both housing production and housing prices in a given suburban jurisdiction. In an open metropolitan area, suburban zoning regulations increase housing prices equally throughout the metropolis and have no interjurisdictional effects. In a closed metropolitan area, the suburban zoning regulation forces a lower supply of new housing in that area. As a result, individuals are forced to find housing in unzoned suburban areas or in the center city. Rubinfeld hypothesizes that this shift in housing results in employment falling in the zoned suburban business area. This leads then to an increase in wages in the zoned area since the marginal product of labor rises. For all individuals in the metropolitan area to be in locational equilibrium, housing prices must rise in the zoned jurisdiction. The housing price increase has an ambiguous effect on center-city housing prices. The interactive effects of zoning on the labor and housing markets result in an interjurisdictional price effect even with identical individuals and perfectly substitutable housing. This hypothetical result-interjurisdictional price changes caused by zoning and other land-use restrictions-can be investigated empirically.

Furthermore, the existence of important information and transaction and mobility costs suggests that housing in different municipalities within a metropolitan area the size of the San Francisco Bay Area will not be perfectly substitutable. Market frictions may prevent the prices of housing units of equivalent quality located in different parts of a metropolitan area from being bid into strict equality. In this case, land-use restrictions in the zoned jurisdiction can raise the price of housing in that jurisdiction relative to the prices in the rest of the metropolitan area as described by a partial equilibrium analysis. (See Rosen and $\mathrm{Katz}^{9}$ for further elaboration.) Following from the above theoretical presentation, we turn now to our empirical analysis.

\section{An Econometric Analysis of the Effects of Growth Controls in the San Francisco Metropolitan Area}

The interjurisdictional effect of land-use and growth controls in the San Francisco Bay Area is analyzed within the context of a cross-sectional

${ }^{8}$ See note 5 supra.

9 See note 3 supra. 
hedonic house price model. The sample analyzed consists of 1,673 singlefamily dwelling units from sixty-three suburban communities within the San Francisco metropolitan area. The data are based on records of house sales obtained from the Society of Real Estate Appraisers (SREA) for the period January-June 1979. The SREA data base provided information on sales price, size, and a number of other structural characteristics of the individual houses sold in the sample time period. Community-level data on journey to work were obtained from the Bay Area's Metropolitan Transportation Commission, and community mean property tax rates, local government expenditures, and population density were provided by various county and state agencies. Finally, the key information on the specific growth-management policies of individual communities were derived from an extensive mail and telephone land-use policy survey of local officials undertaken by the Center for Real Estate and Urban Economics at the University of California, Berkeley. ${ }^{10}$

The basic hedonic price model analyzed hypothesizes that the price of an individual house is a function of its structural characteristics, neighborhood characteristics, local fiscal characteristics, and the land-use and/or growth-management policies of the jurisdiction in which it is located. Our empirical analysis focuses on the effects of formal growth-management programs. The land-use variable utilized is DLU, a dummy variable that takes on the value of one for housing units located within jurisdictions for which a formal growth-management plan had been in effect for at least one year in the 1973-79 period. A formal growth-management plan is defined for the purposes of this study as an explicit numerical limitation on the number of building permits issued within a jurisdiction or a complete moratorium on the issuance of new building permits covering the majority of the community.

The definitions of the variables utilized in the empirical analysis are found in Table 1. The means and standard deviations of the variables also appear in Table 1. Approximately 10.5 percent of the sample consists of units located in jurisdictions with formal growth-management controls. Differences in the sample means for the characteristics of houses located in the formally controlled and uncontrolled growth subsamples are highlighted in Table 2. Dwelling units in controlled communities are on the average a bit larger, more likely to be located in the North Bay, and somewhat more likely to possess a pool and/or a view. Although the mean characteristics for the controlled and uncontrolled subsamples do not

${ }^{10}$ For a detailed analysis of the results of this survey, see Stuart Gabriel, Lawrence Katz, \& Jennifer Wolch, Local Land-Use Regulation and Proposition 13, Taxing \& Spending 73 (Spring 1980). 
TABLE 1

Variable Definitions, Means, and Standard Deviations of the Data $(N=1,673)$

\begin{tabular}{|c|c|c|}
\hline Variable & Description* & Mean \\
\hline HP & House sales price (in dollars) & $\begin{array}{c}93,342 \\
(54,114)\end{array}$ \\
\hline DLU & $\begin{array}{l}\text { Equals one if jurisdiction in which unit is located had } \\
\text { formal growth-management program in existence for at } \\
\text { least one year, 1973-79 }\end{array}$ & .105 \\
\hline SQFT & Square footage of living space of the house & $\begin{array}{l}1,514 \\
(554)\end{array}$ \\
\hline BATH & Number of bathrooms & $\begin{array}{l}1.88 \\
(.695)\end{array}$ \\
\hline POOL & Equals one if pool present & .056 \\
\hline VIEW & $\begin{array}{l}\text { Equals one if significant view present as designated by } \\
\text { reporting real estate broker }\end{array}$ & .142 \\
\hline PTAX & $\begin{array}{l}\text { Community mean property tax rate of jurisdiction in } \\
\text { which unit is located } \dagger\end{array}$ & $\begin{array}{l}4.875 \\
(.521)\end{array}$ \\
\hline TRANS & Commute time to downtown San Francisco (in minutes) & $\begin{array}{c}36.677 \\
(14.101)\end{array}$ \\
\hline AGE & Age in years of the unit & $\begin{array}{c}22.269 \\
(18.908)\end{array}$ \\
\hline FRPLC & Number of fireplaces & $\begin{array}{l}.877 \\
(.507)\end{array}$ \\
\hline TEXP & $\begin{array}{l}\text { Per capita local government (municipal) expenditures of } \\
\text { jurisdiction in which unit is located (in dollars) }\end{array}$ & $\begin{array}{c}247.43 \\
(118.66)\end{array}$ \\
\hline DENSITY & $\begin{array}{l}\text { Population density (per square mile) of jurisdiction in } \\
\text { which unit is located }\end{array}$ & $\begin{array}{c}3,686 \\
(2,165)\end{array}$ \\
\hline EBAY & $\begin{array}{l}\text { Equals one if unit is located in East Bay (Alameda or } \\
\text { Contra Costa counties) }\end{array}$ & .498 \\
\hline NBAY & $\begin{array}{l}\text { Equals one if unit is located in North Bay (Marin, Napa, } \\
\text { Solano, or Sonoma counties) }\end{array}$ & .258 \\
\hline
\end{tabular}

NotE.-Numbers in parentheses are standard deviations.

* Dichotomous variables equal zero otherwise.

$\dagger$ The property tax rate applied to assessed value.

appear extremely different in many dimensions, the difference in mean house price is greater than $\$ 16,000$, with the controlled sector showing higher prices. The issue that our econometric work centers on is whether this house price differential may be explained by the observable differences in structural, fiscal, and neighborhood characteristics.

The first approach to the analysis of the potential effect of growth controls on house prices is the estimation of a hedonic house price equation of the form

$$
\log (\mathrm{HP})=\boldsymbol{X} \boldsymbol{\beta}+\alpha \mathrm{DLU}+\boldsymbol{\epsilon},
$$


TABLE 2

Means of Growth-controlled and -UnControlled SubSamples

\begin{tabular}{|c|c|c|}
\hline Variable & $\begin{array}{l}\text { Controlled } \\
\text { Subsample } \\
(\mathrm{DLU}=1)\end{array}$ & $\begin{array}{c}\text { Uncontrolled } \\
\text { Subsample } \\
(\mathrm{DLU}=0)\end{array}$ \\
\hline HP & $\begin{array}{c}108,725 \\
(55,701)\end{array}$ & $\begin{array}{c}91,549 \\
(53,658)\end{array}$ \\
\hline SQFT & $\begin{array}{c}1,569 \\
(501)\end{array}$ & $\begin{array}{c}1,507 \\
(560)\end{array}$ \\
\hline BATH & $\begin{array}{l}1.960 \\
(.637)\end{array}$ & $\begin{array}{l}1.870 \\
(.701)\end{array}$ \\
\hline POOL & .091 & .051 \\
\hline VIEW & .171 & .139 \\
\hline PTAX & $\begin{array}{l}5.023 \\
(.602)\end{array}$ & $\begin{array}{l}4.858 \\
(.509)\end{array}$ \\
\hline TRANS & $\begin{array}{c}40.910 \\
(11.360)\end{array}$ & $\begin{array}{c}36.182 \\
(14.309)\end{array}$ \\
\hline AGE & $\begin{array}{c}21.634 \\
(17.696)\end{array}$ & $\begin{array}{c}22.343 \\
(19.048)\end{array}$ \\
\hline FRPLC & $\begin{array}{c}.891 \\
(.497)\end{array}$ & $\begin{array}{l}.876 \\
(.508)\end{array}$ \\
\hline TEXP & $\begin{array}{c}222.29 \\
(81.07)\end{array}$ & $\begin{array}{c}250.37 \\
(121.99)\end{array}$ \\
\hline DENSITY & $\begin{array}{c}3,143 \\
(760)\end{array}$ & $\begin{array}{c}3,750 \\
(2,265)\end{array}$ \\
\hline $\begin{array}{l}\text { EBAY } \\
\text { NBAY }\end{array}$ & $\begin{array}{l}.406 \\
.554\end{array}$ & $\begin{array}{l}.509 \\
.223\end{array}$ \\
\hline$N$ & 175 & $1,498^{\circ}$ \\
\hline
\end{tabular}

NotE.-Numbers in parentheses are standard deviations.

where $\boldsymbol{X}$ represents a vector of structural, neighborhood, and fiscal characteristics; $\boldsymbol{\beta}$ is a vector of parameters; $\alpha$ is a parameter; and $\epsilon$ is a stochastic term representing unmeasured factors that affect house prices. The variables included in the specification are those listed in Table 1; also listed are quadratic terms for square footage and age. It is hoped that community-cluster dummy variables (East Bay and North Bay with the Peninsula as the base group) and the population density variable capture major differences in environments, amenities, and nonresidential land use.

One potential problem in the estimation of this equation at the individual house sales transactions level is that data are not available on the property tax rate or the accessibility to San Francisco of each individual unit. Thus community means are used for these two variables. This is a potential errors-in-variables problem arising from measurement error in these independent variables. However, since the variations within juris- 
dictions in the sample of both property tax rates and access times to San Francisco are quite small (especially relative to the variation between community means), it is unlikely that this measurement problem will significantly alter the parameter estimates.

The first column of Table 3 presents the estimates of equation (1). Most of the basic variables are highly significant and are in the predicted directions, with reasonable magnitudes. The equation in our model also is successful in explaining much of the variation within this cross section. The estimated log housing price differential for houses in controlled versus uncontrolled jurisdictions (defined as $\log \left(\mathrm{HP}_{c}\right)-\log \left(\mathrm{HP}_{u}\right)$, where $\mathrm{HP}_{c}$ is the growth-controlled house price and $\mathrm{HP}_{u}$ is the house price in the uncontrolled regime) is .173 with a $t$-statistic of 9.44 . The prices of houses in the formally growth-managed sector appear to be both statistically significant and substantially higher than the prices of observationally equivalent houses in the uncontrolled sector.

Still, the single-equation approach with a single growth-management dummy variable suffers from the defect of explicitly constraining the housing price effect of growth controls to be the same for all houses. This is a problem because growth controls are likely to affect certain types of units much more directly than others. For example, growth-management programs typically provide more constraint on the development of smaller, moderate-quality units than on larger, high-quality units. The potential market reorientation and the market segmentation effects of formal controls mean that the implicit prices attached to specific housing characteristics are likely to diverge across the controlled and uncontrolled market segments. The housing price differential associated with growth controls is likely to vary for houses with different characteristics. This suggests that the single-equation approach may yield somewhat distorted results.

This problem can be handled by estimating separate growth-controlled and -uncontrolled sector house price equations of the form

$$
\begin{aligned}
& \log \left(\mathrm{HP}_{c}\right)=a_{c}+\boldsymbol{X} \boldsymbol{\beta}_{c}+\boldsymbol{\epsilon}_{c}, \\
& \log \left(\mathrm{HP}_{u}\right)=a_{u}+\boldsymbol{X} \boldsymbol{\beta}_{u}+\boldsymbol{\epsilon}_{u} .
\end{aligned}
$$

The results of the estimation of separate equations for the two sectors are shown in columns 2 and 3 of Table 3 . The constant is much larger in the controlled sector equation, and the coefficients on the structural house characteristics' variables tend to be greater in the uncontrolled sector. The positive effect of growth management on house prices appears to be greater for smaller houses, houses with a view, houses in the Peninsula (South Bay), and houses located closer to the central business district. The test of the equality of all the coefficients except the constant terms 
TABLE 3

Estimates of Ordinary Least Squares House Price Equations

\begin{tabular}{|c|c|c|c|}
\hline & $\begin{array}{c}\log (\mathrm{HP}) \\
(1)\end{array}$ & $\begin{array}{c}\log \left(\mathrm{HP}_{c}\right) \\
(2)\end{array}$ & $\underset{(3)}{\log \left(\mathrm{HP}_{u}\right)}$ \\
\hline DLU & $\begin{array}{l}.1730 \\
(.018)\end{array}$ & $\ldots$ & $\ldots$ \\
\hline SQFT & $\begin{array}{l}.00063 \\
(.00004)\end{array}$ & $\begin{array}{l}.00064 \\
(.00015)\end{array}$ & $\begin{array}{l}.00063 \\
(.00005)\end{array}$ \\
\hline BATH & $\begin{array}{l}.025 \\
(.013)\end{array}$ & $\begin{array}{c}-.015 \\
(.033)\end{array}$ & $\begin{array}{l}.031 \\
(.014)\end{array}$ \\
\hline POOL & $\begin{array}{l}.149 \\
(.024)\end{array}$ & $\begin{array}{l}.149 \\
(.047)\end{array}$ & $\begin{array}{l}.157 \\
(.026)\end{array}$ \\
\hline VIEW & $\begin{array}{l}.147 \\
(.007)\end{array}$ & $\begin{array}{l}.178 \\
(.042)\end{array}$ & $\begin{array}{l}.127 \\
(.018)\end{array}$ \\
\hline PTAX & $\begin{array}{r}-.087 \\
(.016)\end{array}$ & $\begin{array}{c}-.133 \\
(.061)\end{array}$ & $\begin{array}{c}-.071 \\
(.017)\end{array}$ \\
\hline TRANS & $\begin{array}{r}-.0052 \\
(.0006)\end{array}$ & $\begin{array}{c}-.0168 \\
(.003)\end{array}$ & $\begin{array}{c}-.0028 \\
(.0007)\end{array}$ \\
\hline AGE & $\begin{array}{c}-.00018 \\
(.00096)\end{array}$ & $\begin{array}{r}-.0080 \\
(.0027)\end{array}$ & $\begin{array}{l}.00051 \\
(.001)\end{array}$ \\
\hline FRPLC & $\begin{array}{l}.088 \\
(.012)\end{array}$ & $\begin{array}{l}.065 \\
(.032)\end{array}$ & $\begin{array}{l}.087 \\
(.013)\end{array}$ \\
\hline TEXP & $\begin{array}{c}-.00031 \\
(.00005)\end{array}$ & $\begin{array}{c}.00023 \\
(.00029)\end{array}$ & $\begin{array}{r}-.00027 \\
(.00005)\end{array}$ \\
\hline DENSITY & $\begin{array}{c}-.000017 \\
(.000003)\end{array}$ & $\begin{array}{l}.000024 \\
(.00005)\end{array}$ & $\begin{array}{c}-.000009 \\
(.000003)\end{array}$ \\
\hline EBAY & $\begin{array}{l}-.142 \\
(.019)\end{array}$ & $\begin{array}{l}-.413 \\
(.121)\end{array}$ & $\begin{array}{c}-.162 \\
(.020)\end{array}$ \\
\hline NBAY & $\begin{array}{c}-.124 \\
(.020)\end{array}$ & $\begin{array}{c}-.509 \\
(.108)\end{array}$ & $\begin{array}{r}-.188 \\
(.023)\end{array}$ \\
\hline $\mathrm{AGE}^{2}$ & $\begin{array}{r}-.0000007 \\
(.000012)\end{array}$ & $\begin{array}{l}.000095 \\
(.00003)\end{array}$ & $\begin{array}{c}-.000013 \\
(.000013)\end{array}$ \\
\hline $\mathrm{SQFT}^{2}$ & $\begin{array}{r}-.00000004 \\
(.00000001)\end{array}$ & $\begin{array}{r}-.00000008 \\
(.00000004)\end{array}$ & $\begin{array}{r}-.00000003 \\
(.00000001)\end{array}$ \\
\hline Constant & $\begin{array}{l}11.164 \\
(.091)\end{array}$ & $\begin{array}{c}12.403 \\
(.328)\end{array}$ & $\begin{array}{r}10.971 \\
(.097)\end{array}$ \\
\hline $\begin{array}{l}\bar{R}^{2} \\
\mathrm{SE}\end{array}$ & $\begin{array}{l}.750 \\
.216\end{array}$ & $\begin{array}{l}.852 \\
.168\end{array}$ & $\begin{array}{l}.750 \\
.214\end{array}$ \\
\hline$N$ & 1,673 & 175 & 1,498 \\
\hline
\end{tabular}

NoTE.-Numbers in parentheses are standard errors.

across the two equations $\left(\mathrm{H}_{0}: \boldsymbol{\beta}_{c}=\boldsymbol{\beta}_{u}\right)$ yields a test statistic that is distributed $F(14,1,643)$ and that takes on the value 7.51 . This hypothesis can be rejected at any reasonable significance level. In conclusion, the growth-management differential varies significantly across houses with different characteristics.

Table 4 reports predicted log house price differentials for a number of house types. These predicted differentials use the coefficient estimates reported in columns 2 and 3 of Table 3 . The log differential at the sample means is .360 . This is substantially larger than the estimated differential 
TABLE 4

Predicted House Price Differentials

\begin{tabular}{lc}
\hline \hline House Description & $\log \left(\mathrm{HP}_{c}\right)-\log \left(\mathrm{HP}_{u}\right)$ \\
\hline Sample means & .360 \\
Controlled subsample (DLU $=1)$ means & .179 \\
Uncontrolled subsample $(\mathrm{DLU}=0)$ means & .381 \\
SQFT $=1,800$, BATH $=2$, POOL $=1$, VIEW $=1$, & \\
PTAX $=5$, TRANS $=38$, AGE $=20$, FRPLC $=1$, & .228 \\
TEXP $=235$, DENSITY $=3,500$, EBAY $=1$ & \\
SQFT $=1,400$, BATH $=1.5$, POOL $=0$, VIEW $=0$, & \\
PTAX $=5$, TRANS $=38$, AGE $=25$, FRPLC $=0$, & .260 \\
TEXP $=235$, DENSITY $=3,500$, EBAY $=1$ & \\
\hline
\end{tabular}

NoTE.-The predicted differentials are based on the estimates in cols. 2 and 3 of Table 3.

from the single-equation approach. The differential associated with formal growth controls appears to vary from about 17 to 38 percent of house price, depending on structural, neighborhood, and local fiscal characteristics.

More than one interpretation of the above data can explain the estimated differences between the house price equations for the controlled and uncontrolled subsamples. The first potential explanation is that these differentials are "real" in the sense that "observationally equivalent" houses will have systematically different prices depending on whether their communities are growth controlled or uncontrolled. This perspective leads to the conclusion that the estimated positive price differentials for growth-controlled communities reflect the supply-restriction and market-reorientation effects of growth-management policies. If this interpretation is correct, then growth controls appear to have resulted in substantial house price increases in those communities in the San Francisco Bay Area where they have been utilized for significant periods of time.

Another possible interpretation of the results is that these differences in house prices could possibly be the "illusory" outcome of weakness in the statistical technique resulting from omitted variables, sample selectivity problems, or both. ${ }^{11}$ The positive price differential for houses in growth-

${ }^{11}$ Heckman discusses empirical techniques for handling dummy endogenous variables and sample selection bias problems. James J. Heckman, Dummy Endogenous Variables in a Simultaneous Equation System, 46 Econometrica 931 (1978); and James J. Heckman, Sample Selection Bias as Specification Error, 47 Econometrica 153 (1979). Freeman and Medoff argue that these techniques often fail to yield useful results because they require exclusion and functional form/distribution restrictions for identification of which we lack the requisite knowledge. Richard B. Freeman \& James L. Medoff, The Impact of Collective Bargaining: Illusion or Reality? in U.S. Industrial Relations, 1950-1980: A Critical Assessment (J. Steiber, R. McKersie, \& D. A. Mills eds., IRRA 1981). 
controlled jurisdictions may reflect structural or neighborhood quality characteristics (not included in the model) that are correlated with the presence of formal growth controls. This is possible but not likely because the addition of extra quality controls as well as other characteristics on the subsample for which additional information was available did not tangibly alter the strength or direction of the results.

A reasonable interpretation of our results is that formal growthmanagement plans appear to have an important interjurisdictional price effect associated with growth controls.

\section{Conclusion and Summary}

This paper has shown, through a careful empirical test based on a large data set on housing in the San Francisco Bay Area, that land-use regulations appear to have had a substantial effect on house prices. Our regression analysis indicates that house prices are between 17 percent and 38 percent higher in those communities in which growth moratoria and/or growth control plans are present.

Our results are not surprising given the widespread use of controls in many communities that limit the available supply response in neighboring communities. The spread of these regulatory techniques to metropolitan areas outside of California may have substantial negative effects on the affordability of housing for the maturing post-World War II baby-boom cohort now entering the housing market.

\section{BIBLIOGRAPHY}

Courant, Paul N. "On the Effect of Fiscal Zoning on Land and Housing Values." Journal of Urban Economics 3 (1976): 88-94.

Dowall, David E. "The Effect of Land Use and Environmental Regulations on Housing Costs." Policy Studies Journal 8 (1979): 277-88.

Freeman, Richard B., and Medoff, James L. "The Impact of Collective Bargaining: Illusion or Reality?'” In U.S. Industrial Relations, 1950-1980: A Critical Assessment, edited by J. Steiber, R. McKersie, and D. A. Mills. Madison, Wis.: IRRA, 1981.

Frieden, Bernard J. "The New Regulation Comes to Suburbia." Public Interest, No. 55 (1979), pp. 15-27.

Gabriel, Stuart; Katz, Lawrence; and Wolch, Jennifer. "Local Land-Use Regulation and Proposition 13." Taxing and Spending (Spring 1980), pp. 73-81.

Hamilton, Bruce W. "Zoning and the Exercise of Monopoly Power." Journal of Urban Economics 5 (1978): 116-30.

$\rightarrow$ Heckman, James J. "Dummy Endogenous Variables in a Simultaneous Equation System." Econometrica 46 (1978): 931-59. 
$\rightarrow$ Heckman, James J. "Sample Selection Bias as Specification Error." Econometrica 47 (1979): 153-61.

Rosen, Kenneth T., and Katz, Lawrence. "Growth Management and Land Use Controls: The San Francisco Bay Area Experience." Journal of American Real Estate and Urban Economics Association 9 (1981): 321-43.

Rubinfeld, Daniel L. "Suburban Employment and Zoning: A General Equilibrium Analysis." Journal of Regional Science 18 (1978): 33-44. 